\title{
USULAN PERBAIKAN PROSES CROSS DRAINAGE UNTUK MEMPERCEPAT WAKTU PROYEK PEMBANGUNAN JALAN RAYA
}

\author{
Mohamad Jihan Shofa, Lanis Listiyana, Dadi Cahyadi \\ Program Studi Teknik Industri, Fakultas Teknik, Universitas Serang Raya \\ Email:m.j.shofa@gmail.com; lanislistyana@gmail.com; dadicahyadi2012@gmail.com
}

\begin{abstract}
Abstrak-Keberhasilan proyek dapat dinilai dari ketepatan waktu terhadap target yang direncanakan. Salah satu permasalahan pada proyek jalan raya adalah pada perbedaan umur proyek cross drainage yang lebih lama dari umur rencana proyek yang telah ditetapkan, sehingga proyek tidak tepat waktu. Penelitian ini bertujuan untuk mengevaluasi proyek cross drainage sehingga diketahui jalur kritis, dan perbaikan apa yang tepat dalam rangka percepatan proyek. Metode Critical Path Method (CPM) digunakan untuk menentukan jalur kritis dari aktivitas proyek cross drainage, dari jalur kritis tersebut akan dilakukan analisis penyebab dengan menggunakan Fishbone Diagram. Selanjutnya dalam penentuan alternatif perbaikan dipilih solusi tepat dengan menggunakan teknik Borda.
\end{abstract}

Katakunci: Borda, Cross Drainage, Critical Path Method, Fishbone Diagram

\begin{abstract}
The success of the project can be judged by the timeliness of the planned target. The problem in the highway project is in the difference between cross drainage age implementation and the age of the project plan that has been set, so that, the project becomes not timely. This research aims to evaluate the critical path of cross drainage project, and what improvements are appropriate in the framework of project acceleration. The Critical Path Method (CPM) method is used to determine the critical path of the cross drainage project activity, from which critical path will be analyzed by using the Fishbone Diagram. Furthermore, borda technique is used to determine the appropriate improvement.
\end{abstract}

Keywords: Borda, Cross Drainage, Critical Path Method, Fishbone Diagram

\section{PENDAHULUAN}

Cross drainage merupakan bagian dari aktivitas proyek pembangunan jalan raya. Dimana aktivitas tersebut perlu diorganisasikan untuk mencapai tujuan dengan anggaran dan sumber daya yang tersedia, dalam jangka waktu tertentu.

Perencanaan dalam suatu proyek sangat penting untuk mencapai keberhasilan proyek tersebut. Namun dalam pelaksanaanya tidak luput dari masalah yang akan dihadapi yaitu terjadinya keterlambatan proyek sehingga perencanaan awal tidak sesuai yang telah dijadwalkan. Salah satu cara untuk meminimalisasi permasalahan dalam pelaksanaan proyek yaitu dilakukannya evaluasi proyek. Mulai dari mengidentifikasi masalah, metode percepatan proyek hingga perbaikan yang akan dilakukan.

Salah satu metode yang biasa digunakan dalam evaluasi penjadwalan proyek adalah
Critical Path Method (CPM). CPM mengevaluasi kegiatan proyek dengan cara menentukan jalur kritis dan durasi proyek. CPM diyakini sebagai alat yang cocok untuk perencanaan dana pengaturan berbagai jenis proyek (Antill \& Woodhead, 1990).

CPM sudah diaplikasikan pada beberapa manajemen proyek, seperti konstruksi pabrik biogas (Zareei, 2018), irigasi (Setiawati, 2017), gedung (Asmaroni, 2016) dan infrastruktur jalan (Nalhadi \& Suntana, 2017; Taurusyanti \& Lesmana, 2015).

Dalam praktek kegiatan proyek, banyak faktor-faktor yang menyebabkan pekerjaan tidak sesuai dengan yang direncanakan. Dengan demikian diperlukan solusi yang sesuai. Salah satu cara yang dapat digunakan untuk pemilihan solusi yang tepat adalah dengan metode borda (Idrus, 2018). Metode ini dapat dipakai menganalisis keberagaman variabel yang diteliti dengan cara menggunakan kuesioner dalam 
pengambilan keputusan (Cahyana, 2014; borda.

Mudzakir, Setiawan, Wibowo, \& Khasani, 2017).

Penelitian ini bertujuan untuk mengevaluasi kegiatan proyek dengan pendekatan CPM dan meminimalkan risiko-risiko keterlambatan dengan metode borda. Penggunaan kedua metode tersebut diharapkan mampu memperbaiki waktu kegiatan proyek crossdrainage.

\section{METODE PENELITIAN}

Penelitian ini berdasarkan data kegiatan yang diambil dari laporan bulanan administrasi teknik pembangunan jalan Pakupatan-Palima, dari tanggal 25 Mei 2015 sampai dengan 25 November 2016.Penelitian fokus pada aktivitas cross drainage, karena merupakan pekerjaan yang sering terlambat, dimana aktivitas cross drain dapat dilihat pada tabel 1 .

Tabel 1. Aktivitas Cross Drainage

\begin{tabular}{|c|c|c|c|}
\hline $\begin{array}{l}\text { Kode } \\
\text { Kegiatan }\end{array}$ & Aktivitas & $\begin{array}{l}\text { Aktivitas } \\
\text { pendahulu }\end{array}$ & Durasi \\
\hline$A 1$ & Mulai & - & 0 \\
\hline$A 2$ & Galian & $A 1$ & 1 \\
\hline A3 & Base $B$ & A2 & 1 \\
\hline A4 & $\begin{array}{l}\text { Besi } \\
\text { lantai } \\
+ \text { +Besi } \\
\text { dinding }\end{array}$ & A3 & 1 \\
\hline A5 & $\begin{array}{l}\text { Bekisting } \\
\text { lantai }\end{array}$ & A4 & 1 \\
\hline A6 & $\begin{array}{l}\text { Bekisting } \\
\text { dinding }\end{array}$ & A4 & 1 \\
\hline A7 & Cor lantai & $A 5, A 6$ & 7 \\
\hline A8 & Perancah & A7 & 1 \\
\hline A9 & $\begin{array}{l}\text { Bekisting } \\
\text { top }\end{array}$ & A8 & 1 \\
\hline A10 & Besi top & A9 & 1 \\
\hline A11 & $\begin{array}{l}\text { Cor } \\
\text { dinding + } \\
\text { Cor top }\end{array}$ & $\mathrm{A} 10, \mathrm{~A} 6$ & 7 \\
\hline A12 & $\begin{array}{l}\text { Bongkar } \\
\text { perancah }\end{array}$ & A11 & 1 \\
\hline A13 & Backfill & A12 & 1 \\
\hline
\end{tabular}

Pengolahan data menggunakan langkah CPM untuk menentukan jalur kritis, dan analisis fishbone digunakan untuk mengetahui penyebab keterlambatan proyek. Solusi perbaikan yang sesuai dilakukan dengan pendekatan metode
Metode CPM sangat bermanfaat dalam perencanaan dan pelaksanaan, pengawasan, pembangunan suatu proyek. CPM membuat asumsi bahwa waktu kegiatan diketahui pasti, hingga hanya diperlukan satu faktor waktu untuk tiap kegiatan. Pada CPM dipakai cara deterministik, yaitu memakai satu angka estimasi. Jadi, disini kurun waktu untuk menyelesaikan pekerjaan dianggap diketahui, kemudian pada tahap berikutnya, diadakan pengkajian lebih lanjut untuk memperpendek kurun waktu, misalnya dengan menambah biaya atau time cost trade-Off atau crash program (Heizer \& Render, 2005).

Untuk menghitung jalur kritis perlu diketahui waktu awal dan waktu akhir antara lain dengan forward pass (perhitungan maju), backward pass (perhitungan mundur), dan slack time. Langkah perhitungan maju adalah jika suatu kegiatan mempunyai satu pendahulu langsung maka Earliest Startnya = EF (Eearlist Finish) dari pendahulu, Jika suatu kegiatan mempunyai beberapa pendahulu langsung Earliest Start nya adalah nilai maximal dari EF pendahulunya $\mathrm{ES}=$ Maximal $(\mathrm{EF}$ semua pendahulu langsung). Aturan waktu selesai terdahulu ( Earliest Finish)suatu kegiatan, jumlah dari waktu mulai terdahulu ES dan waktu kegiatan.

Adapun langkah perhitungan mundur adalah jika suatu kegiatan pendahulu langsung untuk suatu kegiatan, Latest Finishnya = Latest Start dari kegiatan yang secara langsung mengikutinya.Jika suatu kegiatan pendahulu langsung lebih dari suatu kegiatan, LF adalah nilai minimum dari seluruh nilai LSdari kegiatan secara langsung mengikutinya Aturan waktu mulai akhir (Latest Start) suatu kegiatan adalah perbedaan antar waktu selesai terakhir (LF) dan waktu kegiatannya.

$\begin{array}{ll}\text { Earliest Finish } & =\text { Earliest Start }+ \text { Waktu kegiatan } \\ \text { Latest Start } & =\text { Latest Finish }- \text { Waktu Kegiatan } \\ \text { Slack Time } & =\text { Latest Start }- \text { Earliest Start }\end{array}$

Fishbone diagram adalah alat analisis yang menyediakan cara sistematis untuk melihat efek dan penyebabnya yang menciptakan atau berkontribusi terhadap efek tersebut.

Metode Borda diusulkan oleh Hevalier de Borda tahun 1770. Metode ini memperkirakan jumlah nilai yang dirasakan dari kriteria yang berbeda, dan biasanya digunakan ketika ada lebih dari dua calon berkompetisi untuk merebutkan satu tempat. Metode borda merupakan salahsatu metode pengambilan keputusan secara kelompok dengan voting 
(pemungutan suara).

\section{HASIL DAN PEMBAHASAN}

Jaringan kerja CPM untuk crossdrainage memiliki durasi total selama 23 hari. Setelah dilakukan perhitungan slack didapatkan bahwa jalur kritis yaitu A1, A2, A3, A5, A7, A8, A9, A10,
A11, A12, A13 dan non Kritis A6. Hal tersebut sebagaimana pada tampilan gambar 2 .

Pada jalur kritis di ambil aktivitas dengan durasi paling panjang yaitu cor dinding dengan durasi 7 hari. Setelah itu dilakukan analisis penyebab dengan menggunakan fishbone diagram.

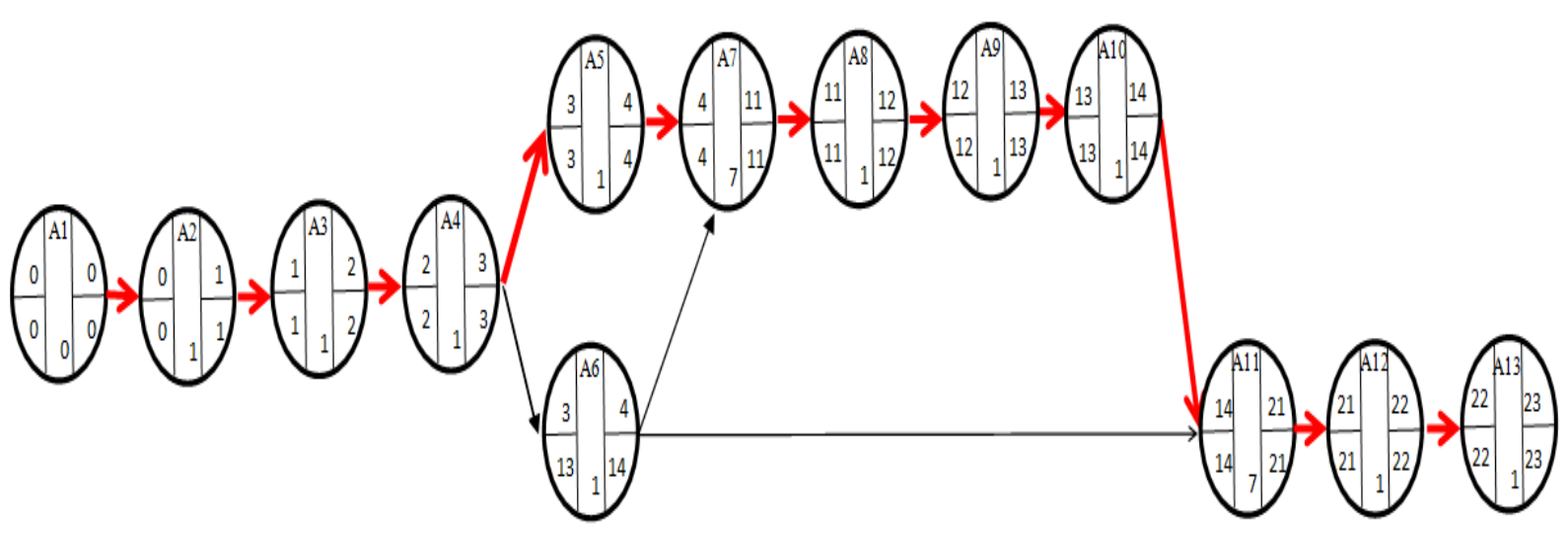

Gambar 2. Activity on Node (AoN) pada Cross drainage

Analisis fishbone dari faktor material dan manusia dapat dilihat pada gambar 3. Untuk akar penyebab dari faktor material adalah keterlambatan pengadaan bekisting, kurangnya pengecekan kualitas bekisting, dan jarak dan waktu tempuh tidak diperhitungkan.

Sedangkan faktor manusia yang menjadi akar penyebab adalah pekerja tidak masuk kerja, pekerja memiliki gangguan kesehatan, sistem K3 yang buruk, kelelahan \& tidak konsentrasi saat kerja, hubungan pekerja dalam kegiatan kurang baik, kurang memahami instruksi kerja, koreksi desain tidak teliti, kurang memahami desain, tidak menggunakan APD sesuai dengan standar yang telah ditetapkan oleh pihak pemimpin proyek.

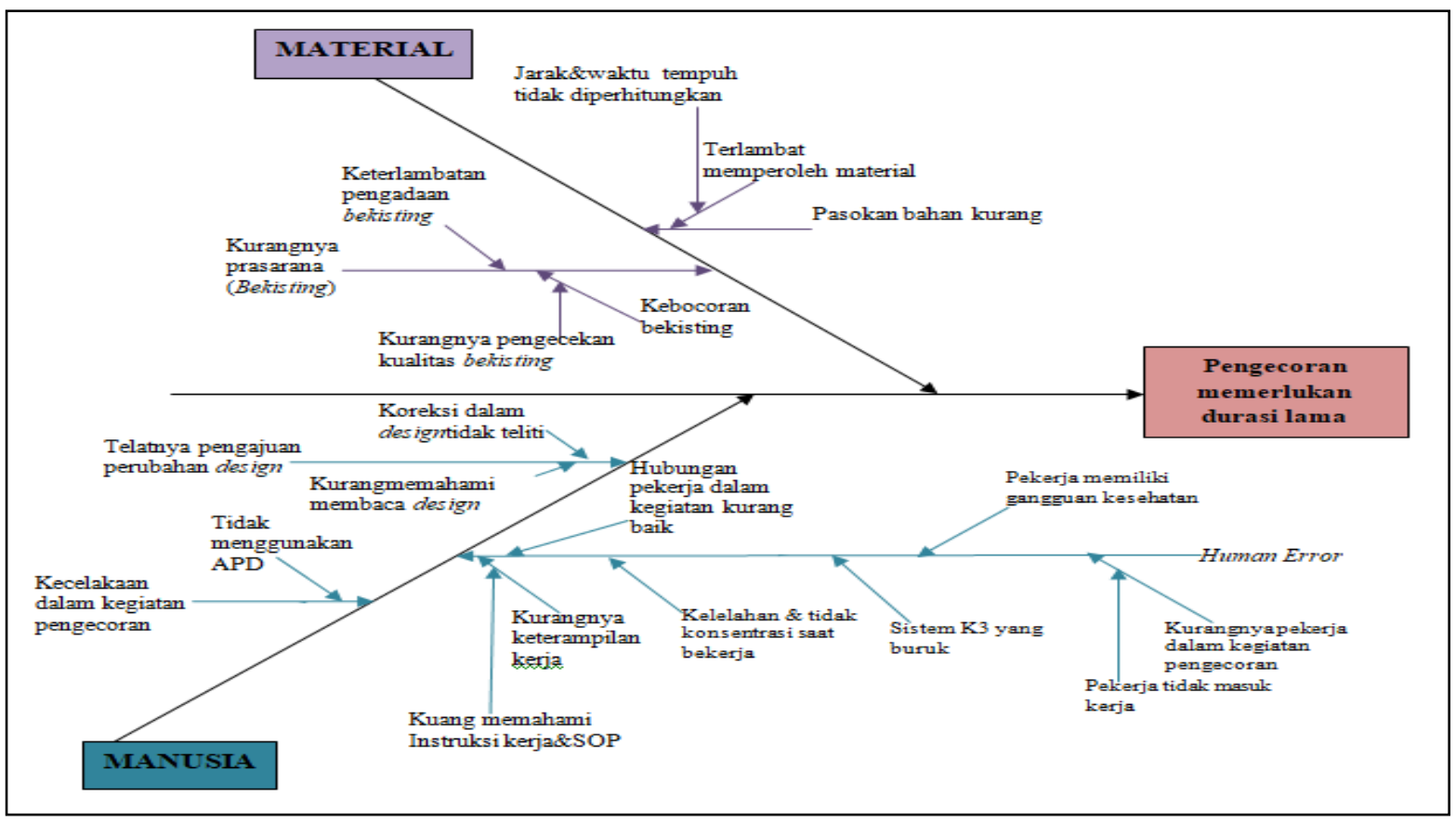

Gambar 3. Fishbone diagram untuk pengecoran lama dari faktor manusia dan material 


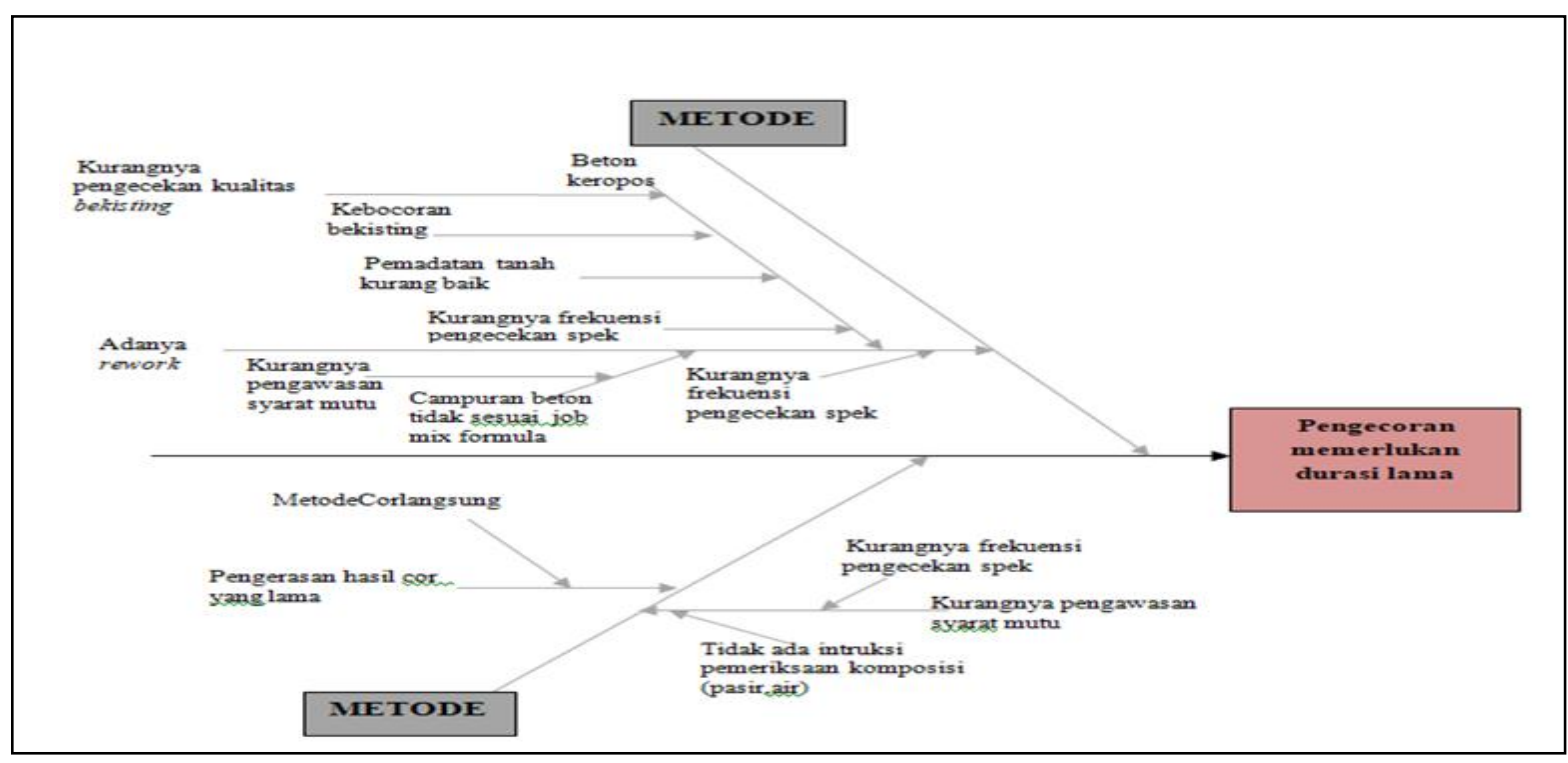

Gambar 4. Fishbone diagram untuk pengecoran lama dari faktor metode

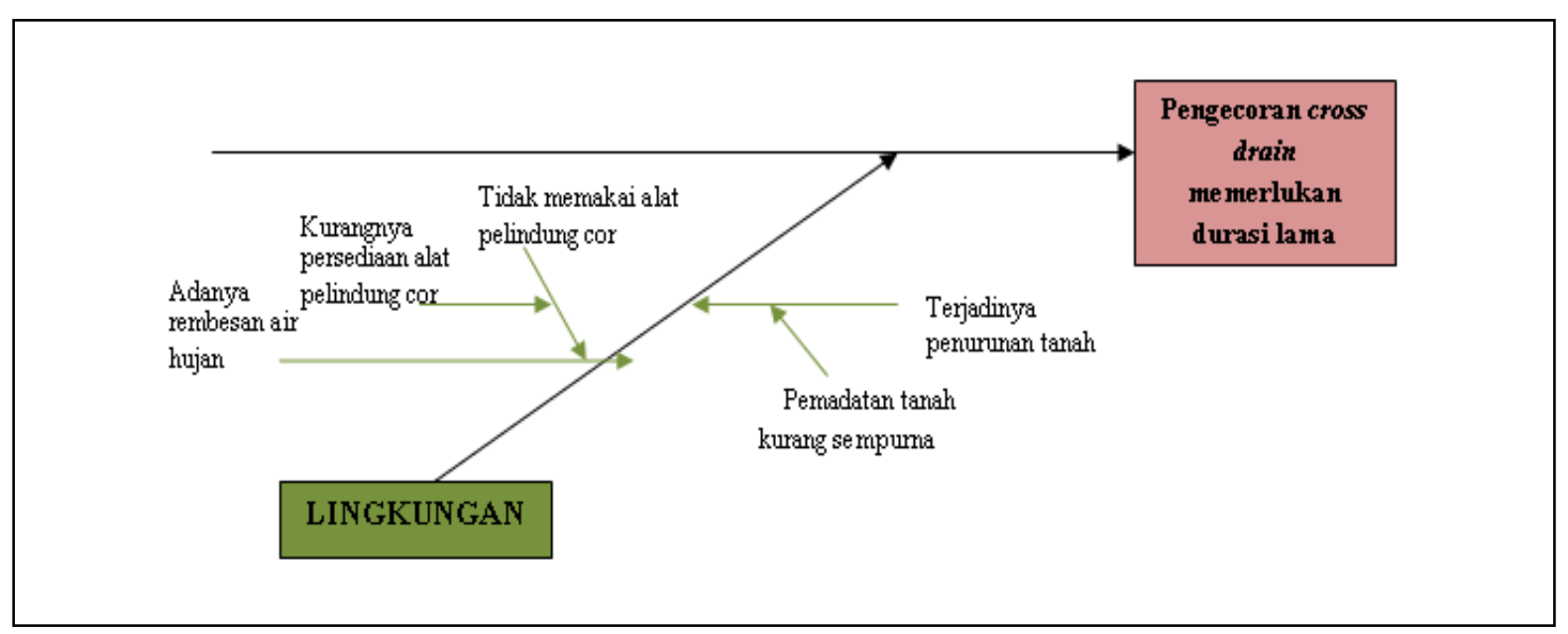

Gambar 5. Fishbone diagram untuk pengecoran lama dari faktor lingkungan

Akar penyebab dari faktor metode adalah kurangnya pengawasan syarat mutu, tidak ada pemeriksaan komposisi, metode pemadatan tanah kurang baik, kurangnya frekuensi pengecekan, kebocoran bekisting, kurangnya pengecekan kualitas bekisting (sama dengan akar penyebab dari faktor material), metode cor langsung, pengerasan hasil cor lama, adanya rework, campuran beton tidak sesuai dengan mix formula (gambar 4). Sedangkan untuk akar penyebab dari faktor lingkungan adalah adanya rembesan air hujan, tidak ada pengadaan alat pelindung, penurunan tanah, dan tidak menggunakan alat pelindung (gambar 5).

Perbaikan masalah tersebut, didapatkan dengan melalui interview kepada project manager (1 orang), project planner (1 orang), supervisor (1 orang), dan technical staff (2 orang). Hasilnya kemudian dilakukan pemilihan perbaikan dengan menggunakan metode Borda, sebagaimana pada Tabel 2 antara lain sharing informasi, serta koordinasi perencanaan (plan) dengan supplier dari sisi material. Untuk masalah manusia dapat dilakukan dengan kontrol absensi pekerja, pengecekan kesehatan periodik, evaluasi sisetem K3, pemerataan beban kerja, pengecekan hasil kerja, pembacaan SOP sebelum bekerja, dan membangun komunikasi dan leadership yang intensif. Dari sisi metode dapat dilakukan laporan kualitas bekisting yang disetujui langsung oleh divisi procurement, tim laborat diawasi langsung oleh konsultan, pemeriksaan kadar optimum air pada tanah, pengecekan ulang oleh konsultan, tim laborat 
diawasi langsung oleh konsultan, peambahan zat additive dengan durasi 3 hari, adanya laporan pengecekan yang disetujui oleh leader.
Sedangkan faktor lingkungan dilakukan perbaikan dengan penyediaan prasarana tenda \& terpal serta pengecekan kadar air lingkungan.

Tabel 2. Akar Penyebab dan Tindakan Terpilih dari Metode Borda

\begin{tabular}{|c|c|c|c|c|}
\hline No & Faktor & Akar Penyebab & Tindakan Perbaikan Terpilih & Bobot \\
\hline \multirow[t]{2}{*}{1} & Material & $\begin{array}{l}\text { Keterlambatan } \\
\text { pengadaanbekisting }\end{array}$ & $\begin{array}{l}\text { Sharing informasi antar procurement, } \\
\text { pelaksana, \&supplier }\end{array}$ & 5 \\
\hline & & $\begin{array}{l}\text { Jarak dan waktu tempuh } \\
\text { tidak diperhitungkan }\end{array}$ & $\begin{array}{l}\text { Koordinasi perencenaan (plan) } \\
\text { dengan supplier }\end{array}$ & 5 \\
\hline \multirow[t]{9}{*}{2} & Manusia & Pekerja tidak masuk kerja & Pengotrolan absensi pekerja & 9 \\
\hline & & $\begin{array}{l}\text { Pekerja memiliki gangguan } \\
\text { kesehatan }\end{array}$ & $\begin{array}{l}\text { Adanya pengecekan kesehatan } \\
\text { periodic }\end{array}$ & 9 \\
\hline & & Sistem K3 yang buruk & Evaluasi sistem K3 & 10 \\
\hline & & $\begin{array}{l}\text { Kelelahan \& tidak konsentrasi } \\
\text { saat bekerja }\end{array}$ & Pemerataan beban kerja & 7 \\
\hline & & $\begin{array}{l}\text { Hubungan pekerja dalam } \\
\text { kegiatan kurang baik }\end{array}$ & Pengecekan hasil kerja pekerja & 8 \\
\hline & & $\begin{array}{l}\text { Kurang memahami Instruksi } \\
\text { kerja }\end{array}$ & $\begin{array}{l}\text { Pembacaan SOP (standard operating } \\
\text { procedure) sebelum bekerja }\end{array}$ & 19 \\
\hline & & $\begin{array}{l}\text { Koreksi dalam design tidak } \\
\text { teliti }\end{array}$ & $\begin{array}{l}\text { Membangun komunikasi } \\
\text { leadership yang intensif }\end{array}$ & 10 \\
\hline & & $\begin{array}{l}\text { Kurang memahami membaca } \\
\text { design }\end{array}$ & $\begin{array}{l}\text { Membangun komunikasi } \\
\text { leadership yang intensif }\end{array}$ & 10 \\
\hline & & Tidak menggunakan APD & $\begin{array}{l}\text { Membangun komunikasi dan } \\
\text { leadership yang intensif }\end{array}$ & 6 \\
\hline \multirow[t]{7}{*}{3} & Metode & $\begin{array}{l}\text { Kurangnya pengecekan } \\
\text { kualitas bekisting }\end{array}$ & $\begin{array}{l}\text { Adanya laporan kualitas bekisting } \\
\text { yang disetujui langsung oleh divisi } \\
\text { procurement }\end{array}$ & 8 \\
\hline & & Kebocoran bekisting & $\begin{array}{l}\text { Pengecekan bekisting sebelum } \\
\text { dipakai }\end{array}$ & 10 \\
\hline & & $\begin{array}{l}\text { Pemadatan tanah kurang } \\
\text { baik }\end{array}$ & $\begin{array}{l}\text { Pemeriksaan kadar air optimum pada } \\
\text { tanah }\end{array}$ & 5 \\
\hline & & $\begin{array}{l}\text { Kurangnya frekuensi } \\
\text { pengecekan spesifikasi }\end{array}$ & Pengecekan ulang oleh konsultan & 8 \\
\hline & & $\begin{array}{l}\text { Kurangnya } \\
\text { syarat mutu }\end{array}$ & $\begin{array}{l}\text { Tim laborat diawasi langsung oleh } \\
\text { konsultan }\end{array}$ & 9 \\
\hline & & Metode cor langsung & $\begin{array}{l}\text { Penambahan zat additive dengan } \\
\text { durasi } 3 \text { hari }\end{array}$ & 9 \\
\hline & & $\begin{array}{l}\text { Tidak ada instruksi } \\
\text { pemeriksaan komposisi }\end{array}$ & $\begin{array}{l}\text { Adanya laporan pengecekan yang } \\
\text { disetujui langsung oleh leader }\end{array}$ & 20 \\
\hline \multirow[t]{2}{*}{4} & Lingkungan & $\begin{array}{l}\text { Kurangnya persediaan alat } \\
\text { pelindung }\end{array}$ & Penyediaan prasarana tenda \& terpal & 5 \\
\hline & & $\begin{array}{l}\text { Pemadatan tanah kurang } \\
\text { sempurna }\end{array}$ & $\begin{array}{l}\text { Pemeriksaan kadar air optimum pada } \\
\text { tanah }\end{array}$ & 5 \\
\hline
\end{tabular}

\section{KESIMPULAN}

Dari analisis yang dilakukan dapat diambil kesimpulan bahwa dengan pendekatanCritical Path Method (CPM) dapat diketahui durasi proyek adalah 23 hari. Sedangkan jalur kritis dengan pendekatan AON (Activity On Node) yaitu pada aktivitas pekerjaan cross drainage. Akar penyebab dari lamanya pekerjaan crossdrainage didapatkan dari analisis fishbone dan solusi yang tepat diusulkan dengan teknik borda. 


\section{DAFTAR PUSTAKA}

Antill, J. M., \& Woodhead, R. W. (1990). Critical path methods in construction practice. John Wiley \& Sons.

Asmaroni, D. (2016). Analisa Keterlambatan Waktu Pelaksanaan Proyek Pembangunan Gedung Pemerintah di Kabupaten Pamekasan. REKAYASA: JURNAL SIPIL, $1(1), 19-23$.

Cahyana, N. H. (2014). Group Decision Support System (GDSS) Untuk Menentukan Prioritas Proyek. Telematika, 10(2), 147152.

Heizer, J., \& Render, B. (2005). Operation Management (Manajemen Operasi) Edisi Ketujuh. Jakarta: Salemba Empat.

Idrus, T. Al. (2018). Faktor-Faktor yang Mempengaruhi Keputusan Nasabah dalam Memilih Produk Rahn di Pegadaian Syariah Ar Hakim Medan dengan Cabang Metode Borda.Skripsi. Universitas Sumatera Utara.

Mudzakir, A. C., Setiawan, A., Wibowo, M. A., \& Khasani, R. R. (2017). Evaluasi Waste Dan Implementasi Lean Construction (Studi Kasus: Proyek Pembangunan Gedung Serbaguna Taruna Politeknik IImu Pelayaran Semarang). JURNAL KARYA TEKNIK SIPIL, 6(2), 145-158.

Nalhadi, A., \& Suntana, N. (2017). Analisa Infrastruktur Desa Sukaci-Baros Dengan Metode Critical Path Method (CPM). Jurnal Sistem Dan Manajemen Industri, 1(1), 3542.

Setiawati, S. (2017). Penerapan Metode CPM Dan PERT Pada Penjadwalan Proyek Konstruksi (Studi Kasus: Rehabilitasi/Perbaikan Dan Peningkatan Infrastruktur Irigasi Daerah Lintas Kabupaten/Kota DI Pekan Dolok). Skripsi. Universitas Sumatera Utara.

Taurusyanti, D., \& Lesmana, M. F. (2015). Optimalisasi Penjadwalan Proyek Jembatan Girder Guna Mencapai Efektifitas Penyelesaian Dengan Metode PERT dan CPM Pada PT Buana Masa Metalindo. JIMFE/ Jurnal IImiah Manajemen Fakultas Ekonomi, 1(1), 32-36.

Zareei, S. (2018). Project scheduling for constructing biogas plant using critical path method. Renewable and Sustainable Energy Reviews, 81, 756-759. 